\title{
Relationships between meteorological and hydrological drought in a young-glacial zone (north-western Poland)based on Standardised Precipitation Index (SPI) and Standardized Runoff Index (SRI)
}

\author{
Katarzyna KUBIAK-WÓJCICKA ${ }^{1}$ * and Włodzimierz JUŚKIEWICZ $Z^{2,3}$
}

\author{
Authors' affiliations and addresses: \\ ${ }^{1}$ Faculty of Earth Sciences and Spatial \\ Management, Nicolaus Copernicus University, \\ Lwowska 1,87-100 Toruń, Poland \\ e-mail: kubiak@umk.pl \\ ${ }^{2}$ Centre for Underwater Archaeology, Nicolaus \\ Copernicus University, Szosa Bydgoska 44/48, 87- \\ 100 Toruń, Poland \\ ${ }^{3}$ Faculty of Social and Technical Sciences, \\ Cuiavian University, Okrzei 94A, 87-800 \\ Włocławek, Poland \\ e-mail: wwj@umk.pl \\ *Correspondence: \\ Katarzyna Kubiak-Wójcicka, Faculty of Earth \\ Sciences and Spatial Management, Nicolaus \\ Copernicus University, Lwowska 1, 87-100 Torun, \\ Poland, \\ tel: 48566112613 \\ e-mail: kubiak@umk.pl \\ How to cite this article: \\ Kubiak-Wójcicka, K. and Juśkiewicz, W. (2020). \\ Relationships between meteorological and \\ hydrological drought in a young-glacial zone \\ (north-western Poland) based on Standardised \\ Precipitation Index (SPI) and Standardized Runoff \\ Index (SRI). Acta Montanistica Slovaca,Volume \\ $25(4), 517-531$ \\ DOI: \\ https://doi.org/10.46544/AMS.v25i4.07
}

\begin{abstract}
This study aims to indicate the relationship between meteorological drought and hydrological drought on the example of a lakeland catchment in north-western Poland. The Standardised Precipitation Index (SPI) and Standardised Runoff Index (SRI) were used to identify drought during 1-, 3-, 6-, 9- and 12-month cumulation periods. In the study period $1971-2015,13$ to 62 meteorological droughts and 6 to 21 hydrological droughts were identified. The highest number of droughts occurred for the shortest cumulation period (1 month) and the lowest number for the longest cumulation period (12 months). The relationship between SPI and SRI coefficients over the annual course was strongest for the 9-month cumulation period. The highest correlation coefficient was obtained for February.
\end{abstract}

\section{Keywords}

Meteorological drought, hydrological drought, Standardised Precipitation Index (SPI), Standardised Runoff Index (SRI), the Drawa River, Poland

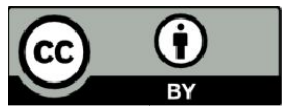

(C) 2020 by the authors. Submitted for possible open access publication under the terms and conditions of the Creative Commons Attribution (CC BY) license (http://creativecommons.org/licenses/by/4.0/). 


\section{Introduction}

Recent years have seen an increased incidence of drought, which is attributed to the observed climate changes (Bordi et al., 2009; Vido et al., 2015; Laaha et al., 2017; Portela et al., 2017; Zeleňáková et al., 2018; Vicente-Serrano et al., 2012; 2019; Kubiak-Wójcicka, 2020). This problem relates to many parts of the world, including Poland. The onset of drought is usually associated with a long-term absence or deficit of precipitation and high air temperatures, leading to a meteorological drought. Atmospheric drought results in quantitative changes in the hydrological cycle. In addition, continuous evapotranspiration reduces the area of surface runoff, reduces soil moisture (soil drought), decreases surface water flows, and lowers the water table; (these are the symptoms of hydrological drought). Hydrological drought thus reflects not only a lack or deficit of precipitation but also a decrease in surface and underground supplies, which is inextricably linked to an area's physiographic and geological conditions (Tokarczyk, 2008). Groundwater droughts are assumed to be the next and usually final stage, after meteorological, agricultural and hydrological drought (Tallaksen \& van Lanen, 2004).

A catchment's response to precipitation deficit varies, depending primarily on the catchment's physiographic characteristics (permeability, topography, land use, land cover) and human activity (regulation of water levels, water abstraction for municipal and industrial purposes) (Lorenzo-Lacruz et al., 2013; Van Lannen et al., 2012; van Loon \& Laaha, 2015; Wang et al., 2015; David \& Davidova, 2016; Kubiak-Wójcicka et al., 2019; van Loon et al., 2019; Afzal \& Ragab, 2019). The complexity of these factors' interactions causes a time lag between meteorological drought and the appearance of hydrological drought, and the difference can stretch to several months (Kubiak-Wójcicka \& Bąk, 2018). Evermore research is being conducted that considers not only climate change but also the particular features of a catchment, including the geological structure and landdevelopment characteristics (Vidal et al., 2012; Fleig et al., 2011; Haslinger et al., 2014; Barker et al., 2016; Kubiak-Wójcicka, 2019a). Despite numerous studies on the relationship between droughts on a global and regional scale, meteorological drought within a catchment extending into other types of drought is extremely important, especially at the local catchment scale (Gibson et al., 2019; Hateren et al., 2019).

Research has focused primarily on arid and semi-arid zones (Kamali et al., 2015; Rangecroft et al., 2016; Li et al., 2017; Bayissa et al., 2018; Zhou et al., 2019). In Poland, areas classed as water-deficit areas of intensive agricultural use have attracted the most research interest (Łabędzki, 2007; Kubiak-Wójcicka, 2019a). The impetus for further research came from the water deficits that occurred in Poland in 2015, and that also affected much of Europe (Laaha et al., 2017;Bąk \& Kubiak-Wójcicka,2017; Ionita et al., 2017; Fendekova et al., 2018; Hänsel et al., 2019; Zuzulová et al., 2019). At that time, droughtaffected not only water-deficit areas in central Poland but also areas of above-average water resources (Kuśmierek-Tomaszewska et al., 2018; Solarczyk \& Kubiak-Wójcicka, 2019; Kubiak-Wójcicka, 2019b; Jamorska et al., 2019). One such river is the Drawa, whose catchment consists mostly of permeable sediments (sands) of considerable thickness. The river itself is only slightly transformed anthropogenically.

This study's main purpose is to identify and quantify meteorological and hydrological droughts and determine their relationship in the Drawa catchment basin. An important part of the study aim is to determine the relationships between hydrological variables' response times to meteorological conditions. Determining the mechanism by which droughts come about will allow for earlier warning against the effects of drought and appropriate water resources management.

\section{Research area}

\section{Methods and Materials}

The Drawa River catchment is located in north-western Poland. The Drawa is $192.08 \mathrm{~km}$ long, and its catchment area is $3,290.93 \mathrm{~km}^{2}$ (Atlas podziału hydrograficznego Polski, 2005). The area has an exceptionally diverse young-glacial relief, with numerous undrained depressions and lake basins and a predominance of permeable formations. The Drawa catchment lies between $220 \mathrm{~m}$ a.s.l. in the north of the catchment and $30 \mathrm{~m}$ a.s.l. in the south. The catchment features geomorphological forms typical of relief shaped by the last glaciation, including a strip of end-moraine hills, hillocky bottom moraine and outwash plain, and glacial channels cutting through areas of moraine and outwash (Fig. 1). Much of the Drawa catchment is covered by extensive outwash fields ranging in thickness from a dozen to several tens of metres (Fig. 2). This area has been called the Drawa Outwash, and it was created in the Pomeranian phase of the Late Pleistocene, i.e. around 16-17 kyr BP. The Drawa Outwash is large for a landform of its type, at $80 \mathrm{~km}$ long (Pisarska-Jamroży, 2015; Woronko et al., 2015). In the north of the Drawa catchment, a small, open-cast sand and gravel mine is in operation. The Drawa catchment is covered to a great extent by forest $(71.06 \%)$ and lakes $(4.52 \%)$. Arable land accounts for only $15.54 \%$ of the catchment and lies in areas of clay, mainly in the north and south-west.

The Drawa catchment area is a lakeland catchment, with a specific drainage structure in which the underground component predominates. Underground outflow accounts for about $80 \%$ of total outflow, while the average for Poland is 55\% (Wrzesiński \& Perz, 2016). The large share of groundwater in the Drawa's supply is due to the existence of the main underground water reservoirs (Główne Zbiorniki Wód Podziemnych - GZWP) 
within the catchment area. These are water-rich geological structures that constitute or may in the future constitute strategic groundwater resources for supplying the population and core branches of the economy needing high-quality water. As per the standard criteria for distinguishing them, the high quality, abundance and potential productive value of the waters make the GZWP the most valuable of hydrostructural units and aquifer systems.



Fig. 1. Geological structure of the Drawa catchment and land use (left corner) by Corine Land Cover (2012) 




Fig. 2. Geological profile (Szczegółowa mapa geologiczna Polski w skali 1:50 000, arkusz Drezdenko)

There are four main underground water reservoirs within the Drawa catchment, i.e. GZWP 125, 127, 136 and 138. The largest by area is GZWP 125 Wałcz-Piła. This reservoir covers almost the entire Drawa catchment, except for a fragment in the north-east and west. GZWP 125 consists of several aquifers within Quaternary formations associated with the fluvioglacial sediments of a moraine plateau, outwashes and alluvia. There are three aquifers within the Quaternary horizons: a surface aquifer (approx. 5-20 m thick), an upper and lower inter-moraine aquifer and a sub-clay horizon(several to $30 \mathrm{~m}$ thick and locally connected with the PaleogeneNeogene level; clay is represented as "tills" in Fig. 2). The reservoir usually lies within sandy formations that are relatively well isolated from the ground surface, but in some areas (the Drawa Outwash region), there is no isolation from the ground surface (Informator PSH, Główne Zbiorniki Wód Podziemnych w Polsce, 2017).

The GZWP 127 reservoir lies in the south-east of the Drawa catchment. It is built of sand and gravel Neogene (Miocene) deposits. The Neogene deposits are often glacitectonically disturbed and cut with deep Quaternary valleys in places. The total thickness of the sandy series is variable, ranging from several to over 50 $\mathrm{m}$.

In the south-west of the Drawa catchment, there is the small Dobiegniew inter-moraine reservoir (GZWP 136). The main usable aquifer in the area ofthe reservoir is the Quaternary layer. Most of the groundwater intakes in this region tap its resources. The main horizon to be exploited is an inter-clay horizon associated with a polygenetic complex of fluvioglacial sands and gravels, with lower layers from the Leszno phase of the Weichselian glaciation and upper layers from the Warta glaciation, plus alluvial deposits of the Eemian interglacial, which form a continuous and extensive layer that constitutes the basic horizon of GZWP 136. The top of the aquifer occurs at varying depths from several to over $50 \mathrm{~m}$ below ground level. The aquifer's thickness varies from less than $10 \mathrm{~m}$ to over $40 \mathrm{~m}$, reaching its maxima in the central part of the reservoir.

GZWP 138 - The Torun-Eberswalde ice-marginal valley. The reservoir consists of a Quaternary, variouslyaged, polygenetic set of aquifers (horizons) from the southern Polish glaciations to the Holocene. The aquifers are of variable thickness, ranging from an average of $20-35 \mathrm{~m}$ in the west to $30-60 \mathrm{~m}$ in the east. The first aquifer's water table is generally unrestricted and occurs at a depth of $1-9 \mathrm{~m}$. It is supplied mainly by the infiltration of precipitation within the reservoir's area and inflow from adjacent plateaus to the north and south, as well as locally by infiltration from the underlying Miocene horizon. The drainage base is the Noteć river (Informator PSH, Główne Zbiorniki Wód Podziemnych w Polsce, 2017).

\section{Data and methods}

This article uses meteorological and hydrological data from the Institute of Meteorology and Water Management of the National Research Institute (IMGW-PIB). The research period is the years 1969-2015. The meteorological data were daily sums of precipitation for four meteorological stations. These are the stations at Łabędzie, Wierzchowo, Lisowo and Krzyż (Table 1). The hydrological data were daily discharges of the Drawa River at the Drawina hydrological station. Station locations are shown in Fig. 1. The average monthly and annual precipitation sums, as well as the average monthly and annual discharges, were calculated from the daily values.

The Standardised Precipitation Index (SPI) used by McKee et al. (1995) was applied to determine meteorological drought. This indicator was calculated using average monthly precipitation sums from the four meteorological stations in the Drawa catchment (Łabędzie, Wierzchowo, Lisowo and Krzyż). Meanwhile, the Standardised Runoff Index (SRI) was used to determine hydrological drought. It is calculated by the same procedure as the SPI index (Shukla \& Wood, 2008; Gao \& Zhang, 2016), but using average monthly discharges of the Drawa river at the Drawina station. As a normalising function, a two-parameter logarithmic function was adopted (Bąk \& Kubiak-Wójcicka, 2017). To calculate SRI values at the different time scales (n months), 
cumulative discharges for each month and for $\mathrm{n}$ months were summed. In total, five different time series were analysed, i.e. 1, 3, 6, 9 and 12 months. The SPI and SRI values determine the deviation from the median, expressed in standard deviations, which was calculated according to the formula:

$$
S P I, S R I=\frac{f(X)-\mu}{\delta}
$$

where:

SPI - Standardised Precipitation Index

$S R I$ - Standardised Runoff Index

$f(X)$ - transformed sum of precipitation, discharges

$\mu$-average normalised index $X$, mean of normalised index $X$

$\delta$ - standard deviation of index $X$

Common classification of drought intensity was adopted for meteorological and hydrological drought, as presented in Table 1. After McKee et al. (1995), it is assumed that during a period of drought, the index values are negative, and also that for at least one month, the value is less than or equal to -1.0 . The drought ends when the index value rises above 0 . The identified drought periods are described using the most common drought parameters. These are frequency - i.e. the number of droughts occurring in the analysed multi-year period; average duration of a single drought; the percentage of months that experienced drought in the analysed multiyear period; longest drought $(\max )$.

\begin{tabular}{c|c}
\multicolumn{2}{c}{ Table 1. Classificationscalefor SPI and SRI values (McKee, Doesken, \& Kleist, 1995) } \\
\hline SPI, SRI & Intensity of drought \\
\hline$<-2.0$ & extremely dry \\
-1.99 to -1.5 & severely dry \\
-1.49 to -1.0 & moderately dry \\
-0.99 to 0.0 & mild dry \\
\hline
\end{tabular}

The correlation coefficient was used to present the relationship between the two drought types for the different cumulation times (1, 3, 6, 9 and 12 months). The higher the correlation coefficient, the stronger the relationships. The correlation between drought types was assumed to be significant when $r>0.5$ (Ljubenkov \& Cindrić Kalin, 2016).

\section{Results and discussion}

\section{Precipitation and discharge in the Drawa catchment in 1971-2015}

The average annual sums of precipitation in the years 1971-2015 ranged from $682.7 \mathrm{~mm}$ at the Łabędzie precipitation station (in the north of the catchment) to $564.3 \mathrm{~mm}$ in Krzyż (the south of the catchment) (Table 2). The north-to-south decline in sums of precipitation is associated with a fall in the terrain and being in the rain shadow of moraine plateaus. The Drawa catchment lies between $220 \mathrm{~m}$ a.s.l. in the north and $30 \mathrm{~m}$ a.s.l. in the south. The lowest precipitation in the studied period was recorded in 1982 at three precipitation stations (the exception being the Lisów station). The highest precipitations were recorded in 1974 (Wierzchowo, Łabędzie), 1981 (Lisowo) and 2012 (Krzyż) (Fig. 3). Averaging the sums of precipitation from the four meteorological stations, the highest mean values occurred in $2010(804.4 \mathrm{~mm})$ and the lowest in $1982(392.4 \mathrm{~mm})$. The average long-term annual sum of precipitation for all four meteorological stations over the entire period of 1971-2015 was $630 \mathrm{~mm}$.

\begin{tabular}{|c|c|c|c|c|c|c|}
\hline \multirow{2}{*}{$\begin{array}{c}\text { Meteorological } \\
\text { station }\end{array}$} & \multirow{2}{*}{ Study period } & \multirow{2}{*}{ Longitude } & \multirow{2}{*}{ Latitude } & \multicolumn{3}{|c|}{ Precipitation (mm) } \\
\hline & & & & average & maximum & minimum \\
\hline Łabędzie & 1971-2014 & 1549 & 5339 & 682.7 & 953.5 & 400.4 \\
\hline Wierzchowo & $1971-2015$ & 1607 & 5328 & 668.5 & 882.7 & 376.1 \\
\hline Lisowo & $1971-2015^{*}$ & 1518 & 5326 & 596.4 & 835.2 & 380.2 \\
\hline Krzyż & $1971-2015$ & 1559 & 5253 & 564.3 & 809.4 & 336.8 \\
\hline
\end{tabular}

The Drawa River discharge is recorded at the Drawiny hydrological station, which encapsulates a $3,281 \mathrm{~km}^{2}$ catchment area. This station is located in the mouth section of the Drawa River. The average annual flow in 1971-2015 was $21.3 \mathrm{~m}^{3} \cdot \mathrm{s}^{-1}$, while the unit outflow was $6.49 \mathrm{dm}^{3} \cdot \mathrm{s}^{-1} \mathrm{~km}^{-2}$. The Drawa's unit outflow was above average for Poland $\left(5.4 \mathrm{dm}^{3} \cdot \mathrm{s}^{-1} 1 \mathrm{~km}^{-2}\right)$ (Kubiak-Wójcicka, 2019b). The average annual Drawa discharges ranged from $15.92 \mathrm{~m}^{3} \cdot \mathrm{s}^{-1}$ to $28.8 \mathrm{~m}^{3} \cdot \mathrm{s}^{-1}$ (Fig. 4). The highest Drawa discharge in the studied period was $51 \mathrm{~m}^{3} \cdot \mathrm{s}^{-1}$ and occurred on March 18, 1981. The lowest discharge $\left(7.91 \mathrm{~m}^{3} \cdot \mathrm{s}^{-1}\right)$ occurred on September 21, 2004 (Kubiak- 
Wójcicka, 2019c). Over the entire study period of 1971-2015, there was a weak downward trend in maximum, average and minimum annual discharges.



Fig. 3. The average annual sum of precipitation (P) for meteorological stations in 1971-2015

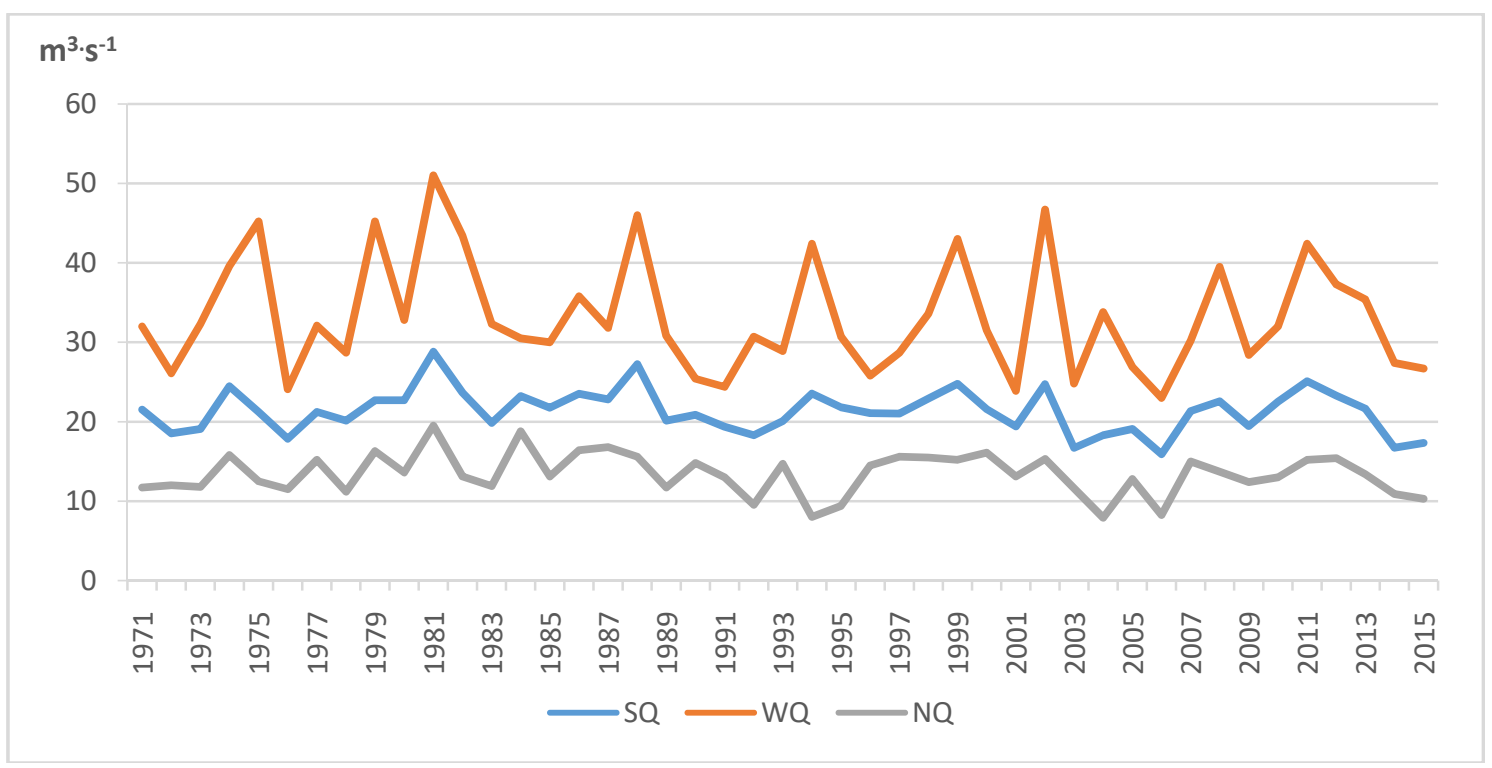

Fig. 4. Average (SQ), maximum (WQ), and minimum (NQ) flows of the Drawa River at the Drawiny station in 1971-2015

During the year, the highest average monthly discharges were recorded in March and April, and the lowest in August and September. Average monthly sums of precipitation were highest in the summer months (July, June and August), and lowest in February (Fig. 5). 


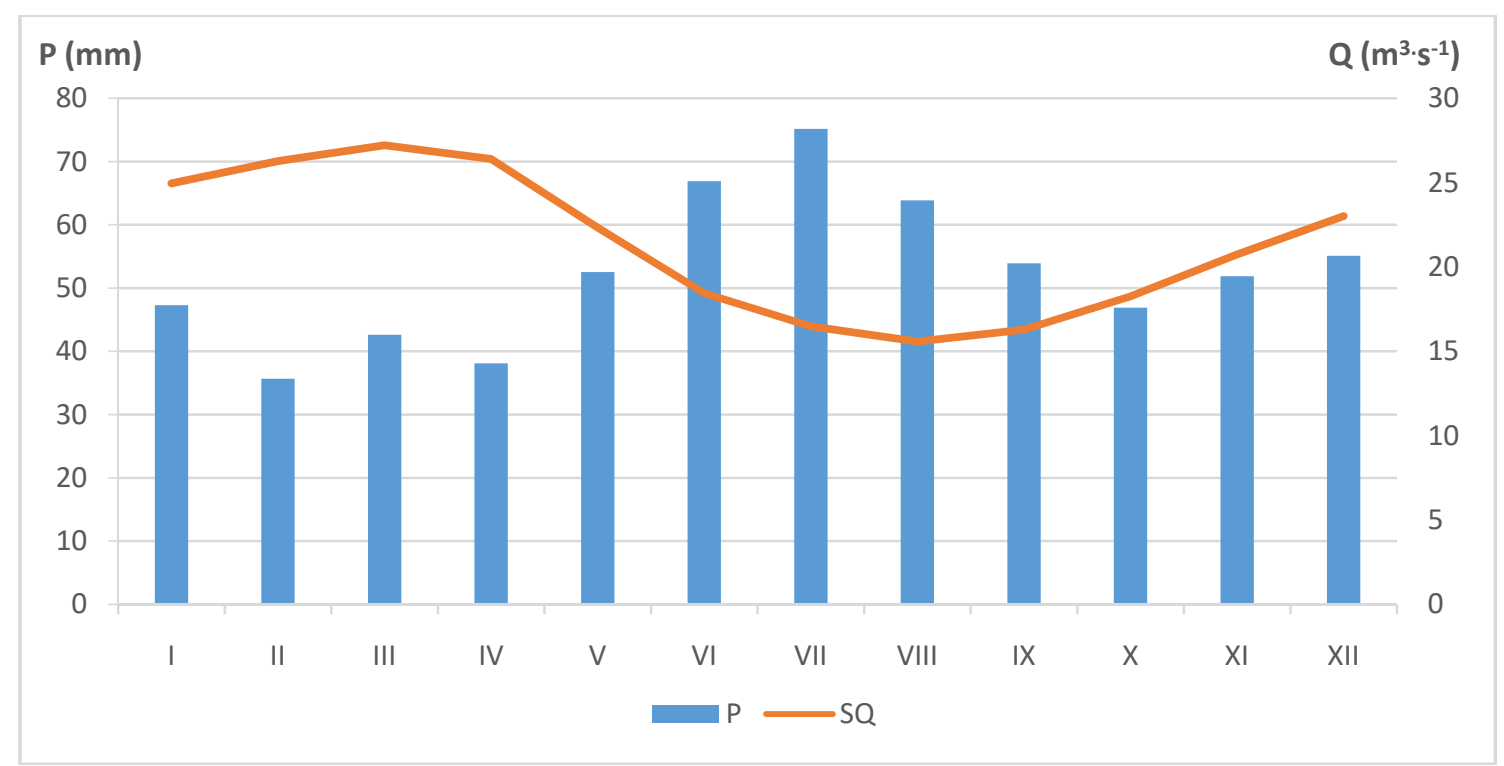

Fig. 5. Average monthly sums of precipitation $(P)$ and average monthly discharges (SQ) of the Drawa River in the Drawiny profile in 1971-2015

\section{The course of SPI and SRI values in 1971-2015}

Figure 6 shows the course of SPI and SRI values over the 1-, 3-, 6-, 9- and 12-month cumulation periods (i.e. SPI-1, SPI-3, SPI-6, etc.). The lowest SPI values for each of the cumulation periods in turn(i.e. SPI-1, SPI-3, etc.) were recorded in November 2011 (SPI-1=-3.19); September 1982 (SPI-3=-3.18); July 1978 (SPI-6=-3.17); November 1982 (SPI-9=-2.96); and November 1982 (SPI-12=-2.87). The lowest SRI values were recorded in September 2004 (SRI-1=-2.66); November 2003 (SRI-3=-2.13); November 2006 (SRI-6=-2.17); November 2006 (SRI-9=-2.22); and December 2006 and January 2007 (SRI-12=-2.23). The highest SPI and SRI values reflect wet periods, while the lowest reflect dry periods.

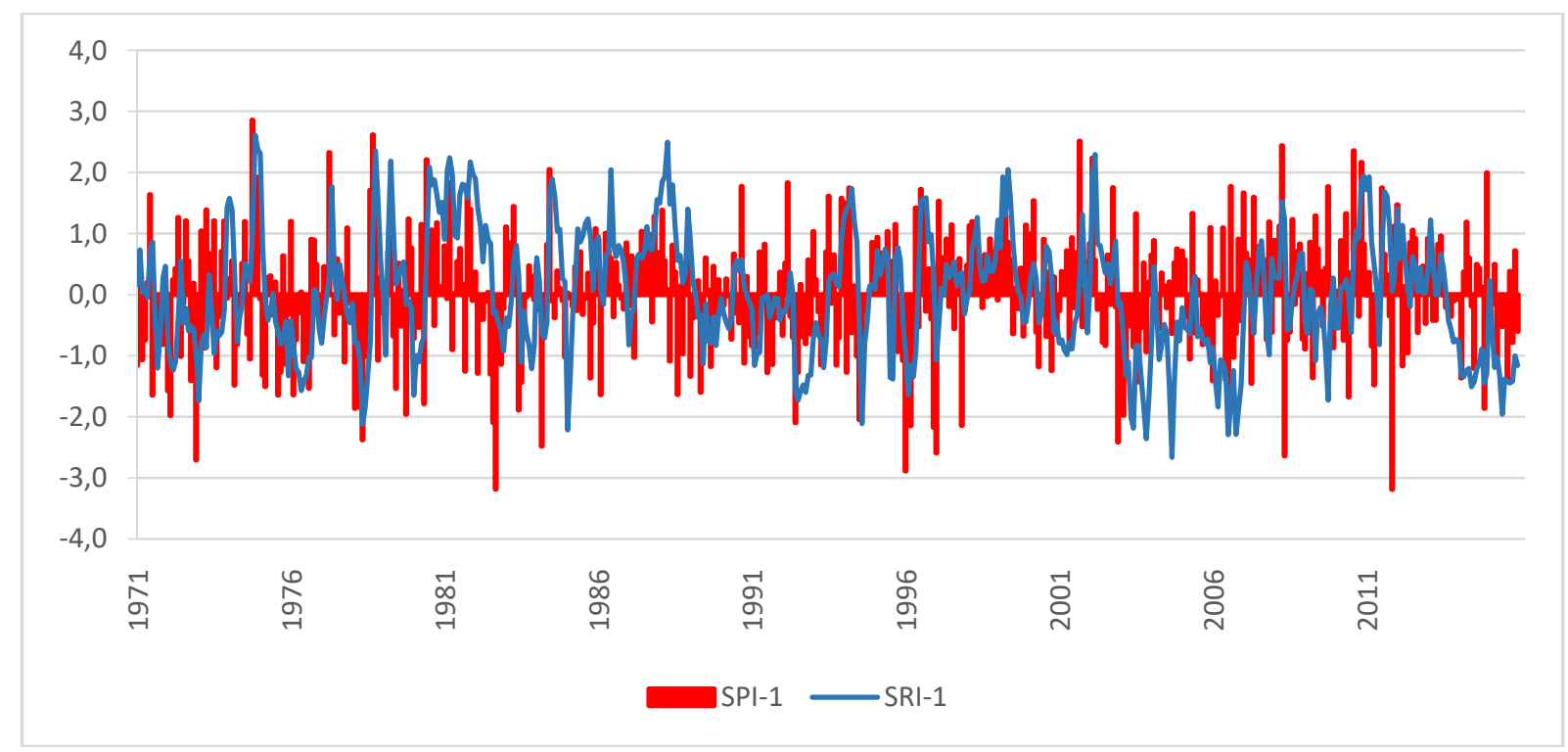











Fig. 6. The course of meteorological and hydrological droughts in the Drawa catchment over 1971-2015 in various cumulation periods $(\mathrm{n}=1,3,6,9$ and 12)

\section{Comparison of drought classes}

All SPI and SRI values below 0 were grouped by drought classes according to Table 1, and then the percentage share of drought periods in each of the various time intervals was calculated (Fig. 7). The total number of individual months with SPI values below 0 ranged from 254 to 269, which accounted for 47\% to $49.8 \%$ of all months in the analysed multi-year period. In turn, the total number of months with SRI values below 0 ranged from $264(48.9 \%)$ to $277(51.3 \%)$. "Mild dry" drought was the largest category by percentage share, which for SPI values ranged from $28.3 \%$ to $34.3 \%$ of all months throughout the entire multi-year period, and for SRI values ranged from $31.3 \%$ to $35.6 \%$. The lowest percentage category was "extreme drought".

Extreme meteorological droughts lasted a total of between 9 and 20 months (i.e. from $1.7 \%$ to $3.7 \%$ of all months of the analysed multi-year period), while extreme hydrological droughts were much shorter, lasting from 3 to 9 months (from $0.6 \%$ to $1.7 \%$ ). The longest total for extreme meteorological drought $(3.7 \%)$ was found for SPI-6; meanwhile, for hydrological drought, conversely, the shortest extreme drought $(0.6 \%)$ was found in the same cumulation period (SRI-6). This means that only one in three extreme meteorological droughts led to the formation of extreme hydrological drought. In the "severely dry" drought class, the share of hydrological droughts increased significantly (from $3.1 \%$ to $6.9 \%$ ), as compared to meteorological droughts, which constituted from $2.8 \%$ to $5.9 \%$. This significant increase in hydrological droughts compared to meteorological droughts in the "severely dry" class was recorded for the SRI-3 and SRI-6 indices. In the remaining classes ("moderately dry" and "mild dry"), the total duration of hydrological drought in all cumulation periods was longer than that of meteorological drought.

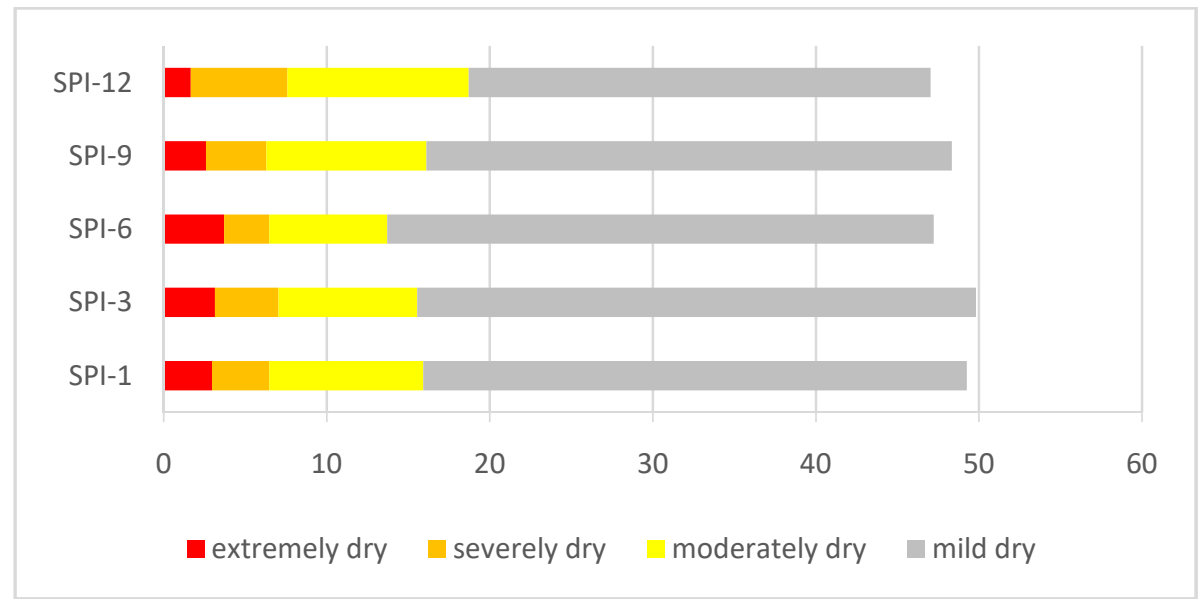




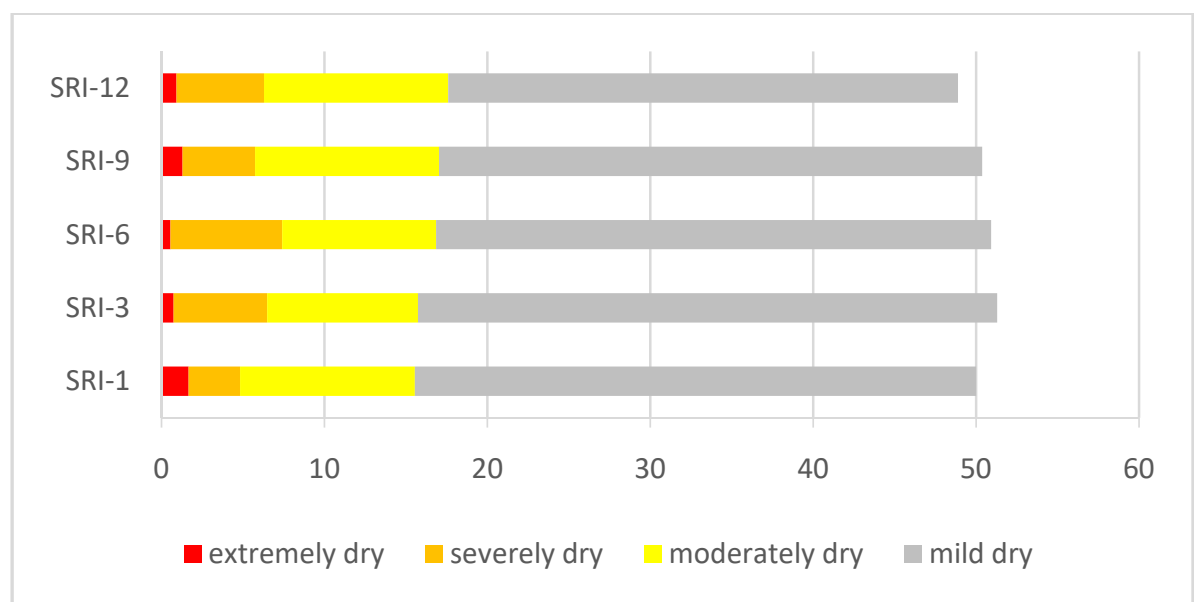

Fig. 7. The percentage share of meteorological (SPI) and hydrological (SRI) drought at various time intervals in 1971-2015

\section{Meteorological and hydrological droughts at various time scales}

For identifying meteorological and hydrological drought, the more stringent criteria for determining drought after McKee et al. (1995) were adopted. Drought only occurs when the index value is below -1.0 , and drought is interrupted when the SPI or SRI index rises above zero.

In the study period 1971-2015, depending on the cumulation period adopted, from 13 to 62 meteorological droughts and from 6 to 21 hydrological droughts were identified. Most droughts were found in the shortest cumulation period ( 1 month) and the fewest in the longest cumulation period (12 months) (Table 3 ). Thirteen meteorological droughts and only six hydrological droughts were found. The average duration of a meteorological drought was from 2 to 5 months (in the 1- and 3-month cumulation periods) and from 9 to 15 months for hydrological drought. As cumulation periods lengthen (6, 9 or 12 months), the number of droughts falls, and their duration rises (averaging 10 to 17 months for meteorological drought and 22 to 32 months for hydrological drought). Thus, as the cumulation period increases, months with drought fall into groups, and thus the number of droughts decreases and the duration of single droughts increases.

Table 3. Characteristics of drought events based on the monthly SPI and SRI index

\begin{tabular}{|c|c|c|c|}
\hline Timescale & Parameters observed & SPI & SRI \\
\hline 1 month & $\begin{array}{c}\text { frequency } \\
\text { average duration } \\
\% \text { of the time under drought } \\
\text { extreme value/data } \\
\text { longest drought }\end{array}$ & $\begin{array}{c}62 \\
2.63 \\
30.2 \\
\text {-3.19 (IX.1982, XI.2011) } \\
8 \text { (VII.1971-II.1972, XII.1977-VII.1978, } \\
\text { XI.2002-VI.2003, VII.2013-I.2014) }\end{array}$ & $\begin{array}{c}21 \\
9.10 \\
35.0 \\
-2.69 \text { (IX.2004) } \\
19 \text { (VII.2005-I.2007) }\end{array}$ \\
\hline 3 months & $\begin{array}{c}\text { frequency } \\
\text { average duration } \\
\% \text { of the time under drought } \\
\text { extreme value/data } \\
\text { longest drought }\end{array}$ & $\begin{array}{c}32 \\
5.19 \\
30.7 \\
-3.18 \text { (IX.1982) } \\
11 \text { (II.1982-XI.1982) } \\
\end{array}$ & $\begin{array}{c}14 \\
15.57 \\
40.4 \\
-2.13 \text { (XII.2003) } \\
49 \text { (II.2003-II.2007) } \\
\end{array}$ \\
\hline 6 months & $\begin{array}{c}\text { frequency } \\
\text { average duration } \\
\% \text { of the time under drought } \\
\text { extreme value/data } \\
\text { longest drought }\end{array}$ & $\begin{array}{c}20 \\
9.65 \\
35.7 \\
-3.17 \text { (VII.1978) } \\
25 \text { (VIII.1988-VIII.1990) }\end{array}$ & $\begin{array}{c}9 \\
21.56 \\
35.9 \\
-2.17 \text { (XI.2006) } \\
53 \text { (II.2003-VI.2007) }\end{array}$ \\
\hline 9 months & $\begin{array}{c}\text { frequency } \\
\text { average duration } \\
\% \text { of the time under drought } \\
\text { extreme value/data } \\
\text { longest drought }\end{array}$ & $\begin{array}{c}13 \\
16.00 \\
38.5 \\
-2.98(\text { XI.1982) } \\
57 \text { (X.1988-VI.1993) }\end{array}$ & $\begin{array}{c}7 \\
25.71 \\
33.3 \\
-2.22 \text { (XI.2006) } \\
53 \text { (III.2003-VII.2007) } \\
\end{array}$ \\
\hline 12 months & $\begin{array}{c}\text { frequency } \\
\text { average duration } \\
\% \text { of the time under drought } \\
\text { extreme value/data } \\
\text { longest drought }\end{array}$ & $\begin{array}{c}13 \\
17.08 \\
41.1 \\
-2.87 \text { (XI.1982) } \\
54 \text { (I.1989-VI.1993) }\end{array}$ & $\begin{array}{c}6 \\
32.00 \\
35.6 \\
-2.23(\mathrm{I} .2007) \\
56(\mathrm{IV} .2003-\mathrm{XI} .2007) \\
\end{array}$ \\
\hline
\end{tabular}

It is worth noting the two persistent droughts that took place in 1989-1994 and 2003-2007. In 1989-1994, there were meteorological droughts that lasted for the 9- and 12-month cumulation periods. For the shorter cumulation periods, there were several meteorological and hydrological droughts that were grouped together in the longer cumulation periods. It was 9- and 12-month cumulations over dry months that gave rise to the longest meteorological droughts and some of the longest hydrological droughts. In the years 1989-94, hydrological 
droughts were milder than meteorological droughts. The response time of hydrological drought to meteorological drought varied depending on drought intensity. The moderately dry meteorological drought of January 1989 caused a mild dry hydrological drought in April 1989 (for a 1-month cumulation period) while, for the 6-month cumulation value, the delay appeared 6 months after the meteorological drought. In June 1992, an extreme meteorological drought (SPI-1=-2.10) was recorded, which resulted in a severely dry hydrological drought (SRI-1=-1.57) simultaneously. The hydrological drought was less intense but lasted longer than the meteorological drought. Drought propagation time depended on the intensity of the meteorological drought. With short-term, mild meteorological droughts, other factors compensating for the precipitation deficit in the catchment played a decisive role. The main one is the groundwater supply. The Drawa River flows in a deeplyincised and very meandering valley, which drains groundwater resources. This relates primarily to the first aquifer, which occurs at a depth of 1 to $9 \mathrm{~m}$. It is mainly supplied by the infiltration of precipitation in the outwash area and inflow from adjacent plateaus to the north and south. An additional element positively affecting the retention of atmospheric precipitation water in the catchment is the area's high level of afforestation, which results in less water being lost by evaporation from the surface. These factors are responsible for mild hydrological droughts not having been provoked by mild meteorological droughts here.

The longest hydrological drought lasted between 19 months (SRI-1) and 56 months (SRI-12). This drought began in April 2003 and ended in November 2007 for SRI-12. It resulted from several meteorological droughts in the period 2003-2007. During this period, hydrological droughts were significantly more intense than meteorological droughts. One reason for this was the high air temperatures recorded in Poland after 2000. In the analysed period, an increase in the number of hot days $\left(\operatorname{Tmax} \geq 30^{\circ} \mathrm{C}\right)$ was recorded in the summer months (June, July, August) and outside the summer months (May, September), which was particularly evident in 2006 (Graczyk et al., 2017). Hot and very hot days led to increased evaporation, which reduced the water resources in the catchment and reduced infiltration deep into the earth. The lack of replenishment of groundwater resources due to the 1989-1994 drought aggravated the existing water deficits, thereby resulting in the 2003-2007 hydrological drought being more intense than the same years' meteorological drought.

The meteorological and hydrological droughts of 1989-1994 also occurred within other Pomeranian river catchments, for example, the Osa, the Gwda (Kubiak-Wójcicka, 2019a, c). The droughts in these years were disastrous and covered most of Poland (Labędzki 2007). Bobiński and Meyer (1992) stated that the most drought-affected regions were the west and north-west of Poland. The most significant water deficits occurred in 1982-1984 and 1990-1992. This was also confirmed in Somorowska (2016) study, which determined droughts using the Standardised Precipitation Evapotranspiration Index (SPEI). She indicated that the droughts in those periods were among the longest and most widespread in Poland. Observations of groundwaters confirm the obtained information. The biggest changes in groundwater levels took place in the early 1990s and were observed as falling water tables in both shallow and deep aquifers. Extremely low levels - hydrogeological low flows - occurred in 1992-1994 in the abundant deeper aquifers. In shallow strata, an extensive drought was also found in the years 2003-2005 (Tarka \& Staśko, 2010). Meteorological and hydrological droughts in 1989-1994 and 2003-2007 also occurred in other regions of Poland and in most of Europe (Fischer et al., 2007; Spinoni et al., 2015; Zeleňáková et al., 2014).

\section{Correlations between SPI and SRI indices}

To determine the relationship between meteorological droughts and hydrological droughts in the Drawa catchment, a correlation analysis was conducted between the SPI and SRI indices using the Pearson correlation test. The results showed that the strongest correlation between SPI and SRI for the whole year was obtained for the 9-month cumulation period $(\mathrm{r}=0.63)$ (Table 4). Of individual months, the highest correlation coefficients between droughts were for February $(\mathrm{r}=0.75)$ for the 9-month cumulation period, while the weakest correlations $(\mathrm{r}<0.5)$ were found for September $(\mathrm{r}=0.47)$ and October $(\mathrm{r}=0.49)$. The correlation was strongest in February because of the accumulated sums of precipitation and total discharges over 9 months, i.e. from June to February. During this period, discharges were more sensitive to the amount of precipitation than they were between January and September (the correlation between SPI and SRI indices was lowest in September). The autumn months' correlation was weak because of other factors affecting the relationship between precipitation and flow. Similar results were obtained in the Osa catchment area, which is largely built of impermeable formations (Quaternary clays), in which arable land dominates, and it is little over one third the size of the Drawa catchment. The strength of the relationship between SPI and SRI in the Osa catchment was decidedly higher, especially for short cumulation periods. For the 1-month cumulation period, the highest correlation index was 0.53, while for 3 months, it reached even 0.7. In turn, the Tokarczyk and Szalińska (2018) study of large catchment areas showed that the largest correlations between SPI and SRI were for longer cumulation periods. The strongest correlations for the Prosna River were found for 12 to 24 months of accumulation and during the 18- to 24-month cumulation periods in the Nysa Kłodzka. In the case of the Vistula, the strongest relations occurred for longer cumulation periods of 18 and 24 months (Kubiak-Wójcicka \& Bąk, 2018). As van Loon and Laaha (2015) indicate, the results obtained may be valid only for regions with similar catchment conditions. 


\begin{tabular}{|c|c|c|c|c|c|c|c|c|c|c|c|c|c|c|c|}
\hline & $\mathrm{I}$ & II & III & IV & $\mathrm{V}$ & VI & VII & VIII & IX & $\mathrm{X}$ & $\mathrm{XI}$ & XII & $\begin{array}{l}\text { X- } \\
\text { III }\end{array}$ & $\begin{array}{c}\text { IV- } \\
\text { IX } \\
\end{array}$ & $\begin{array}{c}\text { I- } \\
\text { XII }\end{array}$ \\
\hline SPI-1vs SRI-1 & 0.38 & 0.33 & 0.43 & 0.23 & 0.06 & 0.46 & 0.42 & 0.21 & 0.28 & 0.20 & 0.17 & 0.24 & 0.29 & 0.28 & 0.28 \\
\hline SPI-3 vs SRI-3 & 0.41 & 0.45 & 0.35 & 0.44 & 0.35 & 0.30 & 0.37 & 0.55 & 0.41 & 0.39 & 0.42 & 0.45 & 0.44 & 0.40 & 0.42 \\
\hline SPI-6 vs SRI-6 & 0.50 & 0.60 & 0.63 & 0.55 & 0.45 & 0.46 & 0.41 & 0.35 & 0.31 & 0.42 & 0.58 & 0.53 & 0.55 & 0.42 & 0.48 \\
\hline SPI-9 vs SRI-9 & 0.66 & 0.75 & 0.74 & 0.74 & 0.72 & 0.68 & 0.64 & 0.52 & 0.47 & 0.49 & 0.53 & 0.62 & 0.63 & 0.63 & 0.63 \\
\hline SPI-12 vs SRI-12 & 0.46 & 0.50 & 0.58 & 0.66 & 0.73 & 0.67 & 0.59 & 0.58 & 0.47 & 0.42 & 0.36 & 0.42 & 0.46 & 0.62 & 0.54 \\
\hline
\end{tabular}

\section{Conclusions}

In this study, the course of meteorological droughts and their impact on hydrological drought on the Drawa River were analysed for the years 1971-2015. The results showed that meteorological droughts were greater in both intensity and number than hydrological droughts for the same cumulation period. In the study period, two periods of persistent droughts were identified in 1989-94 and 2003-07. Annual correlations between meteorological drought and hydrological drought were strongest for the 9-month cumulation period. The poor correlation between droughts obtained for the 1-month cumulation period indicates that the lack or deficit of precipitation did not lead to the formation of hydrological drought. This shows that meteorological drought and hydrological drought do not fully synchronise. In this period, the hydrological conditions of the river are more affected by other factors (for example, groundwater supply), which attenuated the rainfall deficit. The relationship between droughts was slightly stronger in August $(\mathrm{r}=0.55)$, which was associated with a rainfall deficit in a 3-month cumulation period (Jun-Aug). In other months, the relationship between droughts was weaker. It was noted that the values of the correlations between SPI and SRI are significant in longer cumulation periods (6,9 and 12 months). This means that a rainfall deficit during these periods significantly affects the course of hydrological drought, while the other factors are longer as important as they are in short cumulation periods. Knowledge of the relationship between meteorological and hydrological drought expressed by SPI and SRI indicators is important from an economic perspective. Infiltration of precipitation supplies shallow groundwaters, which are the drainage base for rivers. According to Tarka \& Staśko (2010), those most threatened by extreme phenomena are shallow groundwaters, which simultaneously are those that meet the criterion of usability. In the case of long periods of meteorological drought, hydrological drought occurs, which can cause shallow wells or periodic sources to dry out. The occurrence of hydrological drought provides information about a preliminary hydrogeological drought, which may potentially threaten consumable groundwater resources. This is important because the towns in the Drawa catchment area are mainly supplied from groundwater intakes. The conducted research highlighted the features of meteorological and hydrological droughts during the research period in the Drawa catchment, which will help those developing water management strategies to mitigate the negative effects of these changes in the region.

\section{References}

Afzal, M. \& Ragab, R. (2019). Drought risk under climate and land use changes: Implication to water resource availability at catchment scale. Water, 11(9), 1790. https://doi.org/10.3390/w11091790

Atlas podziału hydrograficznego Polski. (2005). Warszawa.

Barker, L.J., Hannaford, J., Chiverton, A., \& Svensson, C. (2016). From meteorological to hydrological drought using standardised indicators. Hydrology and Earth System Sciences, 20, 2483-2505. doi:10.5194/hess20-2483-2016

Bayissa, Y., Maskey, S., Tadesse, T., van Andel, S.J., Moges, S., van Griensven, A., \& Solomatine, D. (2018). Comparison of the performance of six drought indices in characterising historical drought for the Upper Blue Nile Basin, Ethiopia. Geosciences, 8, 81. doi:10.3390/geosciences 8030081

Bąk, B., \& Kubiak-Wójcicka, K. (2016). Assessment of meteorological and hydrological drought in Torun (central Poland town) in 1971-2010 based on standardised indicators. 3rd International Conference water resources and wetlands, Conference proceedings, 8-10 September 2016, Tulcea, Romania, ISSN.2285-7923, 164-170.

Bąk, B.,\& Kubiak-Wójcicka, K. (2017). Impact of meteorological drought on hydrological drought in Toruń (central Poland) in the period of 1971-2015. Journal of Water and Land Development, 32 (I-III), 3-12. doi:10.1515/jwld-2017-0001

Bordi, I., Fraedrich, K., \& Sutera, A. (2009). Observed drought and wetness trends in Europe: an update. Hydrol. Earth Syst. Sci., 13, 1519-1530.

Bobiński,E., \& Meyer, W. (1992). Susze w Polsce w latach 1982-1992. Ocena hydrologiczna. Wiadomości Instytutu Meteorologiii Gospodarki Wodnej, XV, 4, 3-23.

Corine Land Cover (2012). http://clc.gios.gov.pl/index.php/clc-2012/o-projekcie 
David, V., \& Davidová,T. (2016). Assessment of summer drought in 2015 using different indices in the catchment of Blanice River. Procedia Engineering, 162, 45-55. doi: 10.1016/j.proeng.2016.11.010

Fendeková M., Gauster T., Labudová L., Vrablíková D., Danáčová Z., Fendek M., \& Pekárová, P. (2018), Analysing $21 \mathrm{st}$ century meteorological and hydrological drought events in Slovakia. J. Hydrol. Hydromech., 66(4), 393-403. doi: 10.2478/johh-2018-0026

Fischer, E. M., Seneviratne, S. I., Vidale, P. L., Lüthi, D., \& Schär, C. (2007). Soil Moisture - Atmosphere interactions during the 2003 European summer heat wave. Journal of Climate, 20(20), 5081-5099. doi:10.1175/JCLI4288.1

Fleig, A.K., Tallaksen, L.M., Hisdal, H., \& Hannah, D.M. (2011). Regional hydrological drought in northwestern Europe: linking a new regional drought area index with weather types. Hydrol. Process. 25, 1163-1179. doi:10.1002/hyp.7644

Gao, L., \& Zhang, Y. (2016). Spatio-temporal variation of hydrological drought under climate change during the period 1960-2013 in the Hexi Corridor, China. Journal of Arid Land, 8(2), 157-171. doi:10.1007/s40333015-0022-3

Gibson, A. J., Verdon-Kidd, D.C., Hancock, G.R., \& Willgoose, G. (2019). Catchment-scale drought: capturing the whole drought cycle using multiple indicators. Hydrology and Earth System Sciences. https://doi.org/10.5194/hess-2019-311

Haslinger, K., Koffler, D., Schöner, W., \& Laaha, G. (2014). Exploring the link between meteorological drought and streamflow: Effects of climate-catchment interaction. Water Resources Research, 50, 2468-2487. 10.1002/2013WR015051

Hänsel, S., Ustrnul, Z., Łupikasza,E., \& Skalak, P. (2019). Assessing seasonal drought variations and trends over Central Europe. Advances in WaterResources, $127, \quad$ 53-75. https://doi.org/10.1016/j.advwatres.2019.03.005

Informator PSH, Główne Zbiorniki Wód Podziemnych w Polsce. (2017). Państwowy Instytut Geologiczny Państwowy Instytut Badawczy, Warszawa.

Ionita, M., Tallaksen,L.M., Kingston, D.G., Stagge, J.H., Laaha, G., van Lanen, H.A.J., Scholz, P., Chelcea, S.M., \&Haslinger, K. (2017). The European 2015 drought from a climatological perspective. Hydrol. Earth Syst. Sci., 21, 1397-1419. https://doi.org/10.5194/hess-21-1397-2017.

Jamorska, I., Kubiak-Wójcicka, K., \& Krawiec, A. (2019). Dynamics of the status of groundwater in the Polish Lowland: the River Gwda catchment example. Geologos, 25(3), 193-204. doi: 10.2478/logos-2019-0021

Kamali, B., Abbaspour, K.C., Lehmann, A., Wehrli, B., \& Yang, H. (2015). Identification of spatiotemporal patterns of biophysical droughts in semi-arid region - a case study of the Karkheh river basin in Iran. Hydrol.EarthSyst.Sci.Discuss., 12, 5187-5217. doi:10.5194/hessd-12-5187-2015

Kubiak-Wójcicka, K., \& Bąk, B. (2018). Monitoring of meteorological and hydrological droughts in the Vistula basin (Poland). Environ Monit Assess, 190: 691. https://doi.org/10.1007/s10661-018-7058-8

Kubiak-Wójcicka, K. (2019a). Dynamics of meteorological and hydrological droughts in the agricultural catchments. Research for Rural Development, Water Management, 1, 111-117. doi:10.22616/rrd.25.2019.017

Kubiak-Wójcicka, K. (2019b). Long-term variability of runoff of Vistula River in 1951-2015. “Air and Water Components of the Environment" Conference Proceedings, Cluj-Napoca, Romania, 109-120. doi:10.24193/AWC2019_11

Kubiak-Wójcicka, K., (2019c). The course of hydrological drought in the River Drawa catchment (Northern Poland) as characterised by the Standardised Runoff Index. Proceedings of the International Conference of Computational Methods in Sciences and Engineering 2019 (ICCMSE-2019). AIP Conference Proceedings, 2186, 120004. https://doi.org/10.1063/1.5138035

Kubiak-Wójcicka K., (2020). Variability of Air Temperature, Precipitation and Outflows in the Vistula Basin (Poland). Resources, 9(9), 103. https://doi.org/10.3390/resources9090103

Kubiak-Wójcicka, K., Zeleňáková, M., Purcz, P., \& Simonova, D. (2019). The use of a Standardised Runoff Indicator for hydrological characterisation of selected rivers of Poland and Slovakia. Middle Pomeranian Scientific Society of the Environment Protection, 21, 167-183. http://ros.edu.pl/images/roczniki/2019/010_ROS_V21_R2019.pd

Kuśmierek-Tomaszewska, R., Dudek, S., Żarski, J., \& Januszewska-Klapa, K. (2018). Temporal variability of drought in field crops in the region of Kujawsko-Pomorskie, Poland. Agricultural Sciences (Crop Sciences, Animal Sciences). Research Rural Development, 2, 62-68. doi: 10.22616/rrd.24.2018.052.

Laaha, G., Gauster, T., Tallaksen, L.M., Vida,1 J-P., Stahl, K., Prudhomme, Ch., Heudorfer, B., Vlnas, R., Ionita, M., van Lanen, H.A.J., Adler, M-J., Caillouet, L., Delus, C., Fendekova,M., Gailliez, S., Hannaford, J., Kingston, D., van Loon, A.F., Mediero, L., Osuch, M., Romanowicz, R., Sauquet, E, Stagge, J.H., \& Wong, H.W. (2017). The European 2015 drought from a hydrological perspective. Hydrol. Earth Syst. Sci., 21, 3001-3024. doi:10.5194/hess-21-3001-2017. 
Li, Z., Chen, Y., Fang, G., \& Li, Y. (2017). Multivariate assessment and attribution of droughts in Central Asia. Scientific Reports, 7, 1316. doi:10.1038/s41598-017-01473-1

Ljubenkov, I., \& Cindrić Kalin, K. (2016). Evaluation of drought using standardised precipitation and flow indices and their correlations on an example of Sinjskopolje. Gradevinar, 2, 135-143. doi:10.14256/JCE.1337.2015.

Lorenzo-Lacruz, J., Vicente-Serrano, S.M., González-Hidalgo, J.C., López-Moreno, J.I., \& Cortesi, N. (2013). Hydrological drought response to meteorological drought in the Iberian Peninsula. Clim. Res., 58, 117131.

Łabędzki, L. (2007). Estimation of local drought frequency in central Poland using Standardized Precipitation Index SPI. Irrigation and Drainage, 56, 67-77. doi: 10.1002/ird.285.

McKee, T.B., Doesken, N.J., \& Kleist, J. (1995). Drought monitoring with multiple time scales. Preprints of the 9th Conference of Applied Climatology, 15-20 January 1995, Dallas, pp. 233-236.

Pisarska-Jamroży, M. (2015). Factors controlling sedimentation in the Torun-Eberswalde ice-marginal valley during the Pomeranian phase of the Weichselian glaciation: an overview. Geologos, 21, 1, 1-29. doi: 10.1515/logos-2015-0001

Portela, M.M., Zeleňáková, M., Santos, J.F., Purcz, P.,Silva A.T., \& Hlavatá H. (2017). Comprehensive characterisation of droughts in Slovakia. Int. J. Environ. Sci. Dev., 8 (1), 25-29. doi: 10.18178/ijesd.2017.8.1.915

Rangecroft, S., van Loon, A.F., Maureira, H., Verbist, K., \& Hannah, D. M. (2016). Multi-method assessment of reservoir effects on hydrological droughts in an arid region. Earth Syst. Dynam. Discuss., doi:10.5194/esd-2016-57.

Shukla, S., \& Wood, W. (2008). Use of a standardised runoff index for characterising hydrologic drought. Geophysical Research Letters, 35, L02405. doi:10.1029/2007GL032487.

Solarczyk, A., \& Kubiak-Wójcicka, K. (2019). The exhaustion of water resources in the Kuyavian-Pomeranian voivodship in drought condition in 2015. Research for Rural Development, Water Management, 1, 118125. doi:10.22616/rrd.25.2019.018.

Somorowska, U. (2016). Changes in drought conditions in Poland over the past 60 years evaluated by the Standardised Precipitation-Evapotranspiration Index. Acta Geophysica, 64 (6), 2530-2549. doi:10.1515/acgeo-2016-0110

Spinoni, J., Naumann, G., Vogt J., \& Barbosa, P. (2015). The biggest drought events in Europe from 1950 to 2012. Journal of Hydrology: Regional Studies, 3, 509-524. http://dx.doi.org/10.1016/j.ejrh.2015.01.001

Szczegółowa mapa geologiczna Polski w skali 1:50 000, arkusz Drezdenko (N-33-116-B), Państwowy Instytut Geologiczny, 1997

Tallaksen L.M., \& van Lanen H.A.J. (2004). Hydrological drought: processes and estimation methods for streamflow and groundwater. Developments in Water Science, 48, The Elsevier Science B.V.

Tarka, R., \& Staśko, S. (2010). Wahania zwierciadła wód podziemnych jako odzwierciedlenie ekstremalnych sytuacji pogodowych. [In:] Migoń P. (ed.) Wyjątkowe zdarzenia przyrodnicze na Dolnym Śląsku. Rozpr. Nauk. IGiRRUWr, 14, 241-256.

Tokarczyk, T. (2008). Wskaźniki oceny suszy stosowane w Polsce i na świecie. Infrastructure and Ecology of Rural Areas, 7, 167-182.

Tokarczyk, T., \& Szalińska, W. (2018). Drought hazard assessment in the process of drought risk management. $\begin{array}{llllll}\text { Acta Sci. Pol. } & \text { Formatio } & \text { Circumiectus, } & 17 & \text { (3), } & \text { 217-229. }\end{array}$ doi:http://dx.doi.org/10.15576/ASP.FC/2018.17.3.217

van Lanen, H. A. J., Wanders, N., Tallaksen, L.M., \& van Loon, A.F. (2012). Hydrological drought across the world: impact of climate and physical catchment structure. Hydrol. Earth Syst. Sci. Discuss., 9, 1214512192.www.hydrol-earth-syst-sci-discuss.net/9/12145/2012/ doi:10.5194/hessd-9-12145-2012

van Loon, A.F., \& Laaha, G. (2015). Hydrological drought severity explained by climate and catchment characteristics. Journal of Hydrology, 526, 3-14. http://dx.doi.org/10.1016/j.jhydrol.2014.10.059

van Hateren, T.C., Sutanto, S.J., \& van Lanen, H.A.J. (2019). Evaluating skill and robustness of seasonal meteorological and hydrological drought forecasts at the catchment scale - Case Catalonia (Spain). Environment International, 133, 105206. https://doi.org/10.1016/j.envint.2019.105206

Vicente-Serrano, S. M., Beguería, V., Lorenzo-Lacruz, J., Camarero, J.J., López-Moreno, J.I., Azorin-Molina, C., Revuelto, J., Morán-Tejeda, E., \& Sanchez-Lorenzo, A. (2012). Performance of drought indices for ecological, agricultural, and hydrological applications. Earth Interactions, 16, 10, 1-27.

Vicente-Serrano, S. M., Domínguez-Castro F., McVicar T.R., Tomas-Burguera M., Peña-Gallardo M., Noguera I., López-Moreno J.I., Peña D., \& Kenawy A. (2019). Global characterisation of hydrological and meteorological droughts under future climate change: The importance of timescales, vegetation-CO2 feedbacks and changes to distribution functions. International Journal of Climatology, 1-11. doi:10.1002/joc. 6350 
Vidal, J.-P., Martin, E., Kitova, N., Najac, N., \& Soubeyroux, J.-M. (2012). Evolution of spatio-temporal drought characteristics: validation, projections and effect of adaptation scenarios. Hydrol. Earth Syst. Sci., 16, 2935-2955. doi:10.5194/hess-16-2935-2012

Vido, J., Tadesse, T., Šustek, Z., Kandrík, R., Hanzelová, M., Škvarenina, J., Škvareninová, J., \& Hayes, M. (2015). Drought occurrence in Central European Mountainous Region (Tatra National Park, Slovakia) within the period 1961-2010. Hindawi Publishing Corporation, Advances in Meteorology, Article ID 248728, 8 pages

Wang, Y., Li, J., Feng, P., \& Chen, F. (2015). Effects of large-scale climate patterns and human activities on hydrological drought: a case study in the Luanhe River basin, China. Natural Hazards, 76, 1687-1710. doi:10.1007/s11069-014-1564-y

Woronko, B., Pisarska-Jamroży, M., \& van Loon, A.J. (2015). Reconstruction of sediment provenance and transport processes from the surface textures of quartz grains from Late Pleistocene sandurs and an icemarginal valley in NW Poland. Geologos, 21, 2, 105-115. doi: 10.1515/logos-2015-0007

Wrzesiński, D., \& Perz, A. (2016). Cechy reżimu odpływurzek w zlewni Warty. Badania Fizjograficzne, Seria Geografia Fizyczna, 289-304. doi:10.14746/bfg.2016.7.2

Zhou, J., Li, Q., Wang, L., Lei, L., Huang, M., Xiang, J., Feng, W., Zhao, Y., Xue, D., Liu, Ch., Wei, W., \& Zhu, G. (2019). Impact of climate change and land-use on the propagation from meteorological drought to hydrological drought in the Eastern Qilian Mountains. Water,11, 1602. doi:10.390/w1108160

Zeleňáková, M., Purcz, P., Sol'áková T., \& Simonová D. (2014). Assessment of low flows occurrence in chosen river stations in Slovakia. WSEAS Transactions on Environment and Development, 10, 417-422.

Zeleňáková, M., Purcz, P., Blištán P., Vranayová Z., Hlavatá H., Diaconu D.C, \& Portela M.M. (2018). Trends in precipitation and temperatures in Eastern Slovakia (1962-2014). Water, 10(6), 727. https://doi.org/10.3390/w10060727

Zuzulová, V., Žilinský, M., \& Šiška B. (2019). Seasons of drought in Slovakia during the period from 19572016.Acta Regionalia et Environmentalica, 2, 38-44. doi: 10.2478/aree-2019-0008 